\title{
Synthesis of silver nanoparticles by Lactobaciluus acidophilus 01 strain and evaluation of its in vitro genomic DNA toxicity
}

\section{S. Karthick Raja Namasivayam*, Gnanendra Kumar E and Reepika R}

Silver nanoparticles synthesized by dried biomass of Lactobaciluus acidophilus 01 strain was evaluated against toxicity of genomic DNA isolated from bacteria (E. coli) fungi (Beauveria bassiana) algae (Seenedesmus acutus) and human blood adopting standard condition was discussed in the present study. Synthesized silver nanoparticles were characterized by UV-Vis spectroscopy and SEM. The UV-Vis spectroscopy revealed the formation of silver nanoparticles by yielding the typical silver plasmon absorption maxima at $430 \mathrm{~nm}$ and SEM micrograph indicates the uniform spherical particles within the size range of $45 \sim 60 \mathrm{~nm}$. The energy dispersive $X$-ray spectroscopy (EDX) of the nanoparticle confirmed the presence of elemental silver signal as strong peak. The above synthesized silver nanoparticles didn't cause any toxic effect on all the tested genomic DNA at all tested concentrations which reveals nil genomic nanoparticles induced toxicity.

Keywords: Lactobacillus acidophilus; Silver nanoparticles; Antibacterial activity; Biosynthesis

Citation: S. Karthick Raja Namasivayam, Gnanendra Kumar E and Reepika R "Synthesis of silver nanoparticles by Lactobaciluus acidophilus 01 strain and evaluation of its in vitro genomic DNA toxicity", Nano-Micro Lett. 2, 160 (2010). doi: 10.5101/nml.v2i3.p160-163

Nanotechnology is significant on account of its pre-eminence upon the comprehension, use, and control of matter at magnitudes of a minute scale, akin to approaching atomic levels, with which to manufacture new substances, instruments, and frameworks [1]. Nanoparticles possess exceptional physical and chemical properties which lead to rapid commercialisation. Nanotechnology is currently employed as a tool to explore the darkest avenues of medical sciences in several ways like imaging [2], sensing [3], targeted drug delivery [4], gene delivery systems [5] and artificial implants [6]. Hence, nanosized organic and inorganic particles are catching increasing attention in medical applications due to their amenability to biological functionalization [7]. Based on enhanced effectiveness, the new age drugs re-nanoparticles of polymers, metals or ceramics can combat conditions like cancer [8] and fight human pathogens like bacteria [9]. Silver nanoparticles (Ag-np) are among the most commercialised nanoparticles due to their antimicrobial potential. Ag-np based cosmetics, therapeutic agents and household products are in wide use, which raised a public concern regarding their safety associated with human and environmental use. No safety regulations are in practice for the use of these nanomaterials [10]. Production of silver nanoparticles can be achieved through different methods. Chemical approaches are the most popular methods for the production. However, some chemical methods cannot avoid the use of toxic chemicals in the synthesis protocol. Since noble metal nanoparticles such as silver, gold nanoparticles are widely applied to human contacting areas. There is a growing need to develop environmentally friendly processes of nanoparticles synthesis that do not use toxic chemicals [11].

Biological systems have a unique ability to control the structure phase and nano structural topography of the inorganic 
crystals [12]. Biological methods based on microbes such as bacteria are able to absorb and accumulate metals and can be used in the reduction of metal ions and thus known to synthesis of nanoparticles [13]. Now, there are lots of issues are raised on release of nanoparticles and their impact on non target organisms. Environmental Protection Agency, announced its intent to request information regarding analytical test methods, fate and transport in the environment, and other relevant information from manufacturers of nanomaterials [14]. There is now a wider debate about the risks and benefits of the many manufactured nanomaterials [15].

Lactobacillus acidophilus 01 strain used in the study was isolated by serial dilution technique using Modified Lactobacillus Agar (Hi-media, India). The bacterium was identified based on cultural and biochemical characteristics. For inoculum preparation, a loopful of bacterial culture was inoculated in a $250 \mathrm{ml}$ of conical flask containing $100 \mathrm{ml}$ sterile MRS broth. The flask was incubated at $30^{\circ} \mathrm{C}$ for $32 \mathrm{~h}$ on a rotary shaker at $200 \mathrm{rpm}$, and the cells were harvested by centrifugation at $3000 \mathrm{rpm}$ for 15 minutes and the collected cell pellets was dried in hot air oven at $60^{\circ} \mathrm{C}$ for $24 \mathrm{~h}$.

In a typical procedure of nanoparticle synthesis, the dried cell pellets were washed thrice with Milli-Q-deinosied water and the washed cell pellets were transferred to $500 \mathrm{ml}$ of conical flask containing $200 \mathrm{ml}$ of milli-Q-deinosied water and kept on a rotary shaker at $200 \mathrm{rpm}$ for $72 \mathrm{~h}$. After the incubation, the cell suspension was filtered through Whatmann filter paper (no. 1). Silver nitrate $\left(\mathrm{AgNO}_{3}, 1 \mathrm{mM}\right)$ was mixed with $50 \mathrm{ml}$ of cell filtrate in a $250 \mathrm{ml}$ of Erlenmeyer flask and agitated at $30^{\circ} \mathrm{C}$ under dark conditions, the flask was observed for color change from pale yellow to brown. Control was run along with experimental flask.

The reaction mixture was analyzed periodically using UV-Vis spectrophotometer. The absorbance was measured in the range $400 \sim 800 \mathrm{~nm}$, which includes the plasmon absorbance peak of the silver nanoparticles centered at $430 \mathrm{~nm}$. Further the samples were characterized by SEM and EDX. The genomic toxicity of silver nanoparticles was evaluated by obtaining the genomic DNA from bacteria (E. coli) fungi (Beauveria bassiana) algae (Seenedesmus acutus) human blood. Genomic DNA isolation from respective sources was performed by standard methods [15] and the extracted pure DNA was stored at $20 \mu \mathrm{g} / \mathrm{ml}$ in Tris buffer under $\mathrm{pH} 7.8$ at $-20^{\circ} \mathrm{C}$. The aliquots of silver nanoparticles were added separately into the respective purified DNA sample, incubated at $37^{\circ} \mathrm{C}$ for about $24 \mathrm{~h}$. The electrophoresis was done using Tris acetate buffer containing 15 $\mu \mathrm{g} / \mathrm{ml}$ ethidium bromide in mini submarine apparatus at 100 amps for 30 minutes. After electrophoresis the gel was visualized under UV transilluminator.

In the present study, biological synthesis of silver nanoparticles by Lactobacillus acidophilus 01 strain is primarily confirmed by color change of the reaction mixture from pale yellow to brown clearly indicating the formation of silver nanoparticles (see Fig. 1). The characteristic brown color due to the excitation of Plasmon vibrations in the nanoparticles provides a convenient signature of their formation [16]. Synthesized silver nanoparticles are characterized by UV-Vis spectroscope, a strong broad surface Plasmon peak located at $430 \mathrm{~nm}$ on 14th and 21st day (see Fig. 2). The surface plasmon band remains in the range of $420 \sim 440 \mathrm{~nm}$ throughout the reaction period suggesting that the particles are dispersed in the aqueous solution with no evidence for aggregation after the complete of reaction. It has been observed that the nanoparticle solution is extremely stable for more than six months with no signs of aggregation even at the end of this period. It is known that silver cations are highly reactive and tend binding strongly with electron donar groups containing sulphur, oxygen or nitrogen [17]. But Mineian et al. [18] did not observe any extra cellular bio synthesis activity from Lactobacillus acidophilus. When we challenged the cell biomass of Lactobacillus acidophilus, it was observed that the silver was reduced

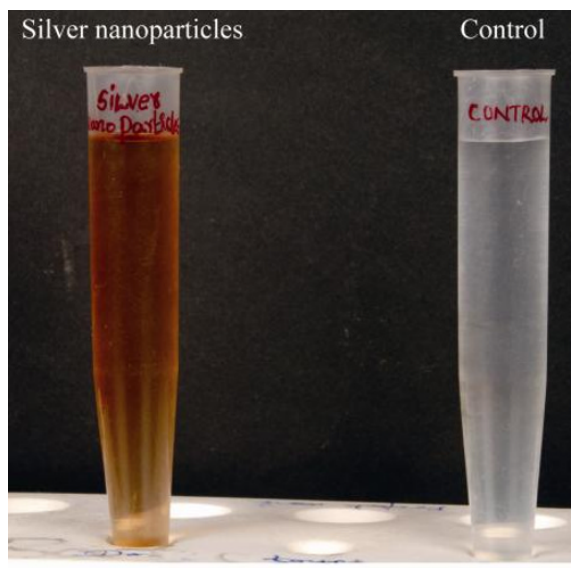

FIG. 1. Reaction mixture with synthesized silver nanoparticles.

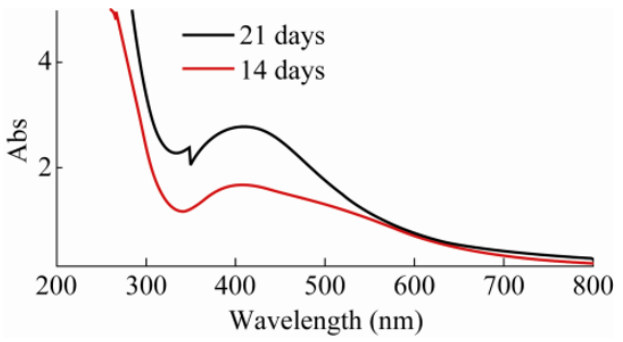

FIG. 2. UV-Vis absorption of silver nanoparticles. 
intracelluarly by Lactobacillus acidophilus. The primordial assay of silver nanoparticles is performed by EDX. Figure 3 shows the EDX spectrum of the silver nanoparticles. Strong signals from the silver particles were observed (42.44\% in mass), while weaker signals from $\mathrm{C}, \mathrm{O}, \mathrm{Al}$ and $\mathrm{S}$ atoms are also recorded. The SEM micrograph at 30000 times magnification was shown in Fig. 4. The SEM micrograph showed spherical nanoparticles with the size range of $45 \sim 60 \mathrm{~nm}$. Mineian et al. [18] got nanopartilces with the size range of $20 \sim 25 \mathrm{~nm}$.

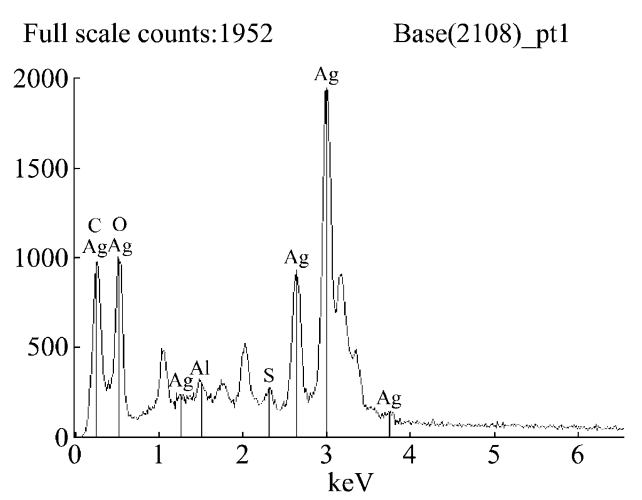

FIG. 3. Energy dispersive spectroscopy spectrum of silver nanoparticles.

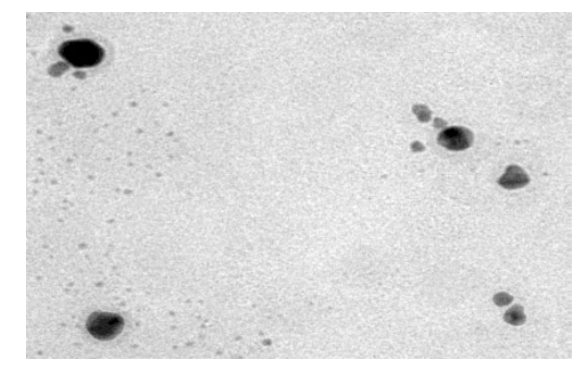

FIG. 4. SEM micrograph of silver nanoparticles.

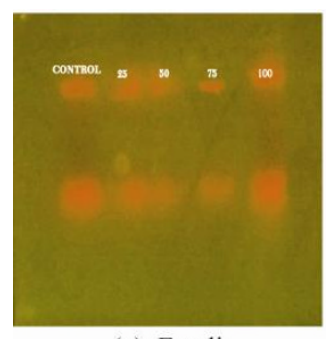

(a) E.coli

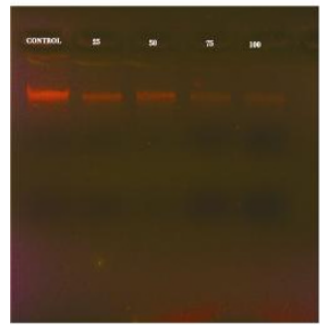

(c) Senedesmus acutus

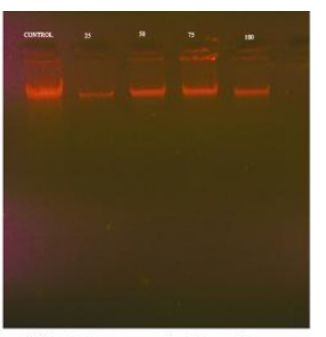

(b) Beauveria bassiana

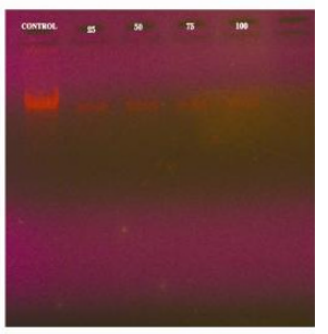

(d) Human Blood
FIG. 5. Agarose electrophorogram of DNA samples treated with silver nanoparticles.

The genomic toxicity with all the tested concentrations of silver nanoparticles didn't show any distinct effect in case that all tested genomic DNA no fragmentation or degradation was observed all in the tested genomic DNA samples. A clear sharp distinct DNA band observed in the entire tested DNA samples as in control (see Fig. 5) clearly reveals the non-toxicity of silver nanoparticles on genomic DNA and its best compatibility with genetic material of the organisms.

The SEM assistance of SAIF, IIT, Chennai is gratefully acknowledged

Received 8 June 2010; accepted 16 July 2010; published online 24 August 2010.

\section{References}

1. Ahmad, P. Mukharjee, S. Senapati, D Mandal and M. Sastry, Colloids Surf. B 28, 313 (2008). doi:10.1016/ S0927-7765(02)00174-1.

2. D. Cui and H. Gao, Biotechnol. Prog. 19, 683 (2003). doi:10.1021/bp025791i.

3. L. Dubas, T. Kulsiriwiwat and K. Samningjam. Acta. Metallurgica Slovaca 13, 1559 (2007).

4. OC. Farokhzad, J. Cheng, B. A. Teply, Sherifi, S. Jon, P. W. Kantoff, JP Richie and R. Langer, Proc. Natl. Acad. Sci. USA. 103, 6315 (2008). doi:10.1073/pnas.0601 755103.

5. R. Feynman, Science 254, 1300 (1991). doi:10.11 26/science.254.5036.1300.

6. C, Greulich, Kittler M. Epple, G. Muhr and Köller, Arch. Surg. 394, 49 (2001).

7. M. James, NNIN REU Research Accomplishments 146, 147 (2004).

8. T. Klaus, R. Joerger, E. Olsson and C. G. Granqvist, Trends Biotechnol. 19, 15 (2001). doi:10.1016/ $\underline{\text { S0167-7799(00)01514-6. }}$.

9. M. Kumar and R. M. Sastry, Nano Lett. 1, 151 (2001).

10. M. Kowshik, A. Ahmad, D. Mandal and S. Senapati, Nanotechnology 14, 95 (2003). doi:10.1088/09574484/14/1/321.

11. P. D. Marcato, G. I. H. DeSiyza, O. L. Alves, E. Esposito and N. Duran, 4th Mercosur Congress on Process Systems Engineering (2008).

12. G. Maribel Guzman, Jean Dille and Stephan Gode, World Academy of Science, Eng. Technol. 43, 17 (2008).

13. P. Mehrbod, N. Motamed, M. Tabatabaian, R. Soleimani Estyar and M. T. Kheri, DARU. 17,121 (2009). 
14. S. Minaeian, A. R. Shahverdi, A. S. Nohi and H. R. Shahverdi, J. Sci. I. A. U. 17, 31 (2009).

15. K. Roy, H. Q. Mao, S. K. Huang and K. W. Leong, Nat. Med. 5, 387 (1999). doi:10.1038/7385.

16. M. V. Rutberg, V. A. Dubina, E. V. Kolikov, E. V. Moiseenko, N. M. Ignateva, Volkov, V. N. Snetov and A. Yu. Stogov, Biochem. Biophys. 421, 193 (2008).
17. E. Sachlos, D. Gotora and J. T. Czernuszka, Tissue Eng. 12, 2479 (2006). doi:10.1089/ten.2006.12.2479.

18. I. H. Sadowski Maliszewska, B. Grochowalska, J. Polowczyk and T. Kozlecki, Mater. Science-Poland 26, 213 (2008). 